\title{
POTENSI AKADEMIK, EFIKASI DIRI DAN KEMANDIRIAN BELAJAR TERHADAP HASIL BELAJAR MATEMATIKA
}

\author{
Ima Arina Arif ${ }^{1}$ \\ Rukli $^{2}$ \\ Nursakiah $^{3 *}$ \\ 1,2,3Universitas Muhammadiyah Makassar, Makassar, Indonesia \\ imaarinaarif@gmail.com ${ }^{1}$ \\ a_rukli@yahoo.co.id ${ }^{2}$ \\ nursakiah@unismuh.ac.id ${ }^{3 *}$
}

\begin{abstract}
Abstrak
Tujuan penelitian ini yaitu untuk mengetahui : 1) pengaruh potensi akademik terhadap hasil belajar siswa pada materi matriks ,2) pengaruh efikasi diri terhadap hasil belajar siswa pada materi matriks , 3) pengaruh kemandirian belajar terhadap hasil belajar siswa pada materi matriks, 4) pengaruh potensi akademik, efikasi diri dan kemandirian belajar terhadap hasil belajar siswa pada materi matriks. Penelitian ini merupakan penelitian ex-post facto. Populasi penelitian ini adalah seluruh siswa kelas XI SMK Negeri 2 Makassar sedangkan sampel dalam penelitian ini yaitu XI TKJ 1 dan XI TKJ 2 yang berjumlah 65 siswa yang diperoleh menggunakan cluster random sampling. Teknik pengumpulan data menggunakan tes dan angket. Teknik analalisis data menggunakan analisis statistik deskriptif dan analisis statistik inferensial. Hasil penelitian ini menujukkan bahwa (1) Secara parsial variabel potensi akademik berpengaruh secara signifikan terhadap hasil belajar matematika siswa kelas XI SMK Negeri 2 Makassar sebesar 17,6\%. (2) Secara parsial variabel efikasi diri berpengaruh secara signifikan terhadap hasil belajar matematika siswa kelas XI SMK Negeri 2 Makassar sebesar 43,4\%. (3) Secara parsial variabel kemandirian belajar berpengaruh secara signifikan terhadap hasil belajar siswa kelas XI SMK Negeri 2 Makassar sebesar 78,8\%. (4) Secara simultan variabel potensi akademik, efikasi diri dan kemandirian belajar berpengaruh signifikan terhadap hasil belajar matematika siswa kelas XI SMK Negeri 2 Makassar dengan koefisien determinasi R2 = 0,817 yang berarti potensi akademik, efikasi diri dan kemandirian belajar memberi pengaruh sebesar $81,7 \%$ terhadap hasil belajar matematika siswa kelas XI SMK Negeri 2 Makassar dan sisanya sebesar 18,3\% dipengaruhi oleh faktor lain.
\end{abstract}

Kata Kunci: Potensi Akademik, Efikasi Diri, Kemandirian Belajar, Hasil belajar.

Diterbitkan Oleh:

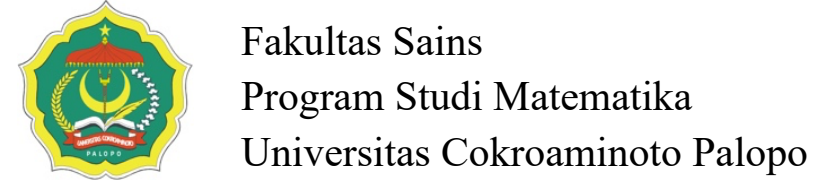

Copyright (C) 2021 The Author (s)

This article is licensed under CC BY 4.0 License

(cc) $\mathrm{BY}$ 


\section{POTENSI AKADEMIK, EFIKASI DIRI DAN KEMANDIRIAN BELAJAR TERHADAP HASIL BELAJAR MATEMATIKA}

\section{Pendahuluan}

Salah satu mata pelajaran yang menjadi dasar kurikulum wajib pada setiap sekolah adalah matematika. Ilmu matematika bukanlah hanya sekedar kumpulan angka serta berbagai macam rumus tetapi matematika disamping sebagai bahasa simbolis juga merupakan bahasa universal yang memungkinkan manusia memikirkan, mencatat, serta mengkominikasikan ide. Dalam kehidupan sehari-hari secara tidak sadar matematika berperan dalam kehidupan mungkin dalam bentuk sederhana dan bersifat rutin atau mungkin dalam bentuk yang sangat kompleks. Sebagai contoh sederhananya dalam melakukan transaksi jual beli para pedagang di pasar yang begitu mahir dan cepat menghitung jumlah pembelian dan sekaligus mengembalikan sisa uang pembeliannya.

Matematika merupakan pelajaran yang penting untuk dipelajari karna (1) Dengan belajar matematika kita mampu berhitung dan mampu melakukan perhitungan-perhitungan lainnya (2) Matematika merupakan persyaratan untuk beberapa mata pelajaran lainnya (3) Dengan belajar matematika perhitungan menjadi lebih sederhana dan praktis (4) Dengan belajar matematika diharapkan kita mampu menjadi manusia yang berpikir logis, kritis, tekun, bertanggung jawab dan mampu menyelesaikan persoalan (Siregar, 2017: 5). Dengan demikian matematika menjadi mata pelajaran yang penting di pelajari untuk meningkatkan potensi akademik.

Potensi akademik sangatlah berkaitan dengan pencapaian hasil belajar siswa. Potensi akademik merupakan suatu kemampuan/kecerdasan yang dimiliki seseorang/individu dalam bidang akademik umum, yang berisi (1) kemampuan verbal/bahasa meliputi persamaan kata (sinonim), lawan kata (anonim), hubungan kata (analogi), (2) kemampuan kuantitatif meliputi aritmetika (hitungan), seri angka, seri huruf, logika angka dan tes dalam cerita (3) penalaran meliputi penalaran logis dan penalaran analitik dan (4) spasial meliputi klasifikasi gambar, pemikiran perseptual, pandang ruang, dan visualitasasi.

Menurut Bandura (Sunardi, 2015: 2), perasaan efikasi diri siswa mempengaruhi pilihan aktivitas mereka, tujuan mereka dan usaha serta persistensi mereka dalam aktivitas-aktivitas di kelas. Namun terkadang masih terdapat siswa yang kurang memiliki kepercayan diri (keyakinan) tentang sejauh mana kemanpuan yang dimilikinya untuk mengatasi hambatanhambatan yang berkaitan dengan proses pembelajaran. Pada hal didalam teori menyebutkan bahwa efikasi diri adalah keyakinan siswa tentang sejauh mana kemampuan yang dimilikinya 
yang dapat digunakan untuk melakukan tindakan yang tepat dalam mengatasi masalah hambatan yang berkaitan dengan tugas-tugas yang diberikan oleh guru. Dengan demikian efikasi diri pun pada akhirnya mempengaruhi pembelajaran dan prestasi mereka.

Selain itu berdasarkan penelitian yang dilakukan oleh Agustini Besse Nurul (2016) menunjukkan bahwa potensi akademik berpengaruh positif terhadap prestasi belajar. Lalu berdasarkan penelitian yang dilakukan oleh Titin Kurnia Bungsu (2015) menunjukkan bahwa terdapat pengaruh positif yang signifikan antara kemandirian belajar terhadap hasil belajar matematika. Serta berdasarkan penelitian yang dilakukan oleh Anggi Ajeng Widganinggar (2015) menunjukkan terdapat pengaruh secara langsung efikasi diri terhadap prestasi belajar matematika.

Berdasarkan hasil observasi yang dilakukan pada saat magang 3 tepatnya pada bulan agustus sampai november 2018 di SMKN 2 Makassar yaitu pada saat pemberian materi khususnya materi matriks kemampuan siswa pada operasi hitung matriks seperti penjumlahan, pengurangan, dan perkalian matriks masih kurang sehingga ketika diberikan latihan pemecahan soal ternyata hanya sebagian siswa yang dapat mengerjakannya dengan baik, sebagian besar tidak tahu apa yang harus dikerjakan. Selain itu para siswa masih merasa malas untuk mempelajari matematika menurut mereka matematika itu adalah pelajaran yang sulit untuk dimengerti/dipahami sehingga sering kali siswa kesulitan dalam mencapai hasil belajar matematika yang maksimal. Salah satu penyebabnya adalah karena mereka sering merasa tidak yakin bahwa dirinya akan mampu menyelesaikan tugas-tugas yang dibebankan kepadanya, atau dengan kata lain kurangnya keyakinan siswa tersebut terhadap kemampuan dirinya untuk menyelesaikan tugas secara berhasil. Keyakinan tersebut biasa disebut dengan efikasi diri. Pada hal telah diketahui bahwa efikasi diri sangatlah berpengaruh pada hasil belajar siswa. Oleh karena itu kurangnya efikasi diri siswa dalam mengerjakan tugas yang diberikan mereka lebih cenderung suka untuk menyontek dibandingkan mengerjakan tugasnya sendiri. Ini membuktikan bahwa kemandirian belajar siswa masih kurang pada hal disekolah siswa dituntut untuk bisa mandiri dalam mengerjakan tugas yang diberikan.

Berkaitan dengan proses pembelajaran di sekolah, siswa dikatakan telah mampu belajar secara mandiri apabila telah mampu melakukan tugas belajar tanpa ketergantungan dengan orang lain. Ketidak tergantungan pada orang lain disebut sebagai sebuah kemandirian. Kemandirian dalam belajar dapat diartikan sebagai aktivitas belajar dan berlangsungnya lebih didorong oleh kemauan sendiri, pilihan sendiri dan tanggung jawab sendiri dari siswa. Tujuan dari penelitian ini adalah untuk mengetahui pengaruh potensi akademik, efikasi diri dan kemandirian belajar dari hasil belajar matematika siswa kelas XI SMKN 2 makassar. 


\section{Metode Penelitian}

Jenis penelitian ini adalah ex-post facto yang bersifat kausalitas. Penelitian ini dilakukan di SMK Negeri 2 Makassar. Populasi dalam penelitian ini adalah seluruh siswa kelas XI SMK Negeri 2 makassar. Teknik pengambilan sampel dalam penelitian ini adalah cluster random sampling dengan memilih dua kelas secara acak dari 10 kelas yang ada untuk menentukan kelas penelitian. Kelas dalam penelitian ini adalah XI TJK 1 dan XI TKJ yang terdiri dari 65 siswa. Adapun teknik analisis data yang digunakan dalam penelitian ini adalah Tes dan angket.

\section{Hasil Penelitian dan Pembahan}

\subsection{Hasil Penelitian}

\section{a. Deskripsi Data}

Berikut ini hasil analisis deskriptif menunjukkan deskripsi tentang karakteristik distribusi nilai dari masing-masing kelas penelitian (Lihat Tabel 1, Tabel 2, Tabel 3 dan Tabel 4).

Tabel 1. Statistik Deskriptif Potensi Akademik

\begin{tabular}{lc}
\hline \multicolumn{1}{c}{ Statistik } & Nilai Statistik \\
\hline Mean & 60,00 \\
Standar Deviasi & 12,406 \\
Variansi & 153,906 \\
Minimum & 30,00 \\
Maksimum & 80,00 \\
\hline
\end{tabular}

Tabel 2. Statistik Deskriptif Efikasi Diri

\begin{tabular}{lc}
\hline Statistik & Nilai Statistik \\
\hline Mean & 59,03 \\
Standar Deviasi & 6,675 \\
Variansi & 44,562 \\
Minimum & 45,00 \\
Maksimum & 70,00 \\
\hline
\end{tabular}

Tabel 3. Statistik Deskriptif Kemandirian Belajar

\begin{tabular}{lc}
\hline Statistik & Nilai Statistik \\
\hline Mean & 57,85 \\
Standar Deviasi & 9,920 \\
Variansi & 98,413 \\
Minimum & 37,00 \\
Maksimum & 75,00 \\
\hline
\end{tabular}


Tabel 4. Statistik Deskriptif Hasil Belajar

\begin{tabular}{lc}
\hline Statistik & Nilai Statistik \\
\hline Mean & 59,77 \\
Standar Deviasi & 13,123 \\
Variansi & 172,212 \\
Minimum & 20,00 \\
Maksimum & 80,00 \\
\hline
\end{tabular}

\section{b. Uji prasyarat}

Tabel 5. Tabel Distribusi Uji Normalitas Menggunakan Ko. lmogrov Smirnov One-sample Kolmogrov- Smirnov Test

\begin{tabular}{lcccc}
\hline & $\mathrm{X} 1$ & $\mathrm{X} 2$ & $\mathrm{X} 3$ & $\mathrm{Y}$ \\
\hline Asymp. Sig. (2-tailed) & 705 & 257 & 739 & 632 \\
\hline
\end{tabular}

Berdasarkan Tabel 5 maka dapat disimpulkan bahwa data dari keempat variabel penelitian yaitu potensi akademik, efikasi diri, kemandirian belajar dan hasil belajar menunjukkan semua sampel lebih dari 0,05 sehingga $\mathrm{H}_{1}$ diterima. Dengan demikian data dari semua sampel penelitian berditribusi normal.

Tabel 6. Hasil Uji Multikolinearitas

\begin{tabular}{lcc}
\hline \multicolumn{1}{c}{ Variabel } & Tolerance & VIF \\
\hline Potensi Akademik & 0,822 & 1.217 \\
\hline Efikasi Diri & 0,582 & 1.719 \\
\hline Kemandirian Belajar & 0,637 & 1.569 \\
\hline
\end{tabular}

Berdasarkan Tabel 6 nilai VIF dari ketiga variabel $<10$ sehingga dapat disimpulkan bahwa pada ketiga variabel bebas tidak terjadi masalah multikolinearitas.

Tabel 7. Uji Linearitas

\begin{tabular}{lccc}
\hline Korelasi & F & Sig. & Keterangan \\
\hline $\mathrm{X} 1, \mathrm{Y}$ & 0,416 & 0,921 & Linear \\
\hline $\mathrm{X} 2, \mathrm{Y}$ & 1,057 & 0,425 & Linear \\
\hline $\mathrm{X} 3, \mathrm{Y}$ & 1,158 & 0,335 & Linear \\
\hline
\end{tabular}

Berdasarkan Tabel 7 maka dapat disimpulkan bahwa data dari ketiga model garis regresi yang diuji menunjukkan nilai sig. $<0,005$ sehingga $\mathrm{H}_{1}$ diterima. Dengan kata lain semua model regresi yang diuji berpola linear. 


\section{c. Uji hipotesis}

Hipotesis 1:

Tabel 8. Koefisien Uji Regresi linear $\mathrm{X}_{1}$ terhadap $\mathrm{Y}$

\begin{tabular}{llll}
\hline Model & \multicolumn{2}{l}{$\begin{array}{l}\text { Unstandardized } \\
\text { Coefficients }\end{array}$} & $\mathrm{P}$ \\
\cline { 2 - 3 } & $\mathrm{B}$ & $\begin{array}{l}\text { Std. } \\
\text { Error }\end{array}$ & \\
\hline (Constant) & 33.180 & 7.412 & 0,000 \\
Potensi & 0,443 & 0,419 & 0,001 \\
akademik & & & \\
\hline
\end{tabular}

Berdasarkan output analisis regresi sederhana pada table 7 coefficients, dapat dilihat nilai $\beta_{1}=0,443$ dengan nilai $\mathrm{P}$ Value $=0,001$ pada taraf signifikan $\alpha=0,05$. Karena nilai $\mathrm{P}$ Value lebih kecil dari nilai $\alpha$ yaitu $0,000<0,05$, maka hal tersebut berarti $\mathrm{H}_{0}$ ditolak dan $\mathrm{H}_{1}$ diterima, sehingga dapat disimpulkan bahwa terdapat pengaruh signifikan potensi akademik terhadap hasil belajar matematika siswa kelas XI SMKN 2 Makassar sebesar 17,6\%. Dari data tersebut dapat disusun persamaan regresinya sebagai berikut: $Y=33,180+0,443 X_{1}$.

Hipotesis 2:

Tabel 9. Koefisien Uji Regresi linear $\mathrm{X}_{2}$ terhadap $\mathrm{Y}$

\begin{tabular}{llll}
\hline Model & \multicolumn{2}{l}{$\begin{array}{l}\text { Unstandardized } \\
\text { Coefficients }\end{array}$} & $\mathrm{P}$ \\
\cline { 2 - 3 } & $\mathrm{B}$ & $\begin{array}{l}\text { Std. } \\
\text { Error }\end{array}$ & \\
\hline (Constant) & -16.721 & 11.064 & 0,136 \\
Efikasi Diri & 1,296 & 0,186 & 0,000 \\
& & & \\
\end{tabular}

Berdasarkan output analisis regresi sederhana pada tabel 9 coefficients, dapat dilihat nilai $\beta_{2}=1,296$ dengan nilai $\mathrm{P}$ Value $=0,000$ pada taraf signifikan $\alpha=0,05$. Karena nilai $\mathrm{P}$ Value lebih kecil dari nilai $\alpha$ yaitu $0,000<0,05$, maka hal tersebut berarti $\mathrm{H}_{0}$ ditolak dan $\mathrm{H}_{1}$ diterima, sehingga dapat disimpulkan bahwa terdapat pengaruh signifikan efikasi diri terhadap hasil belajar matematika siswa kelas XI SMKN 2 Makassar sebesar 43,4\%. Dari data tersebut dapat disusun persamaan regresinya sebagai berikut: $Y=-16,721+1,296 X_{2}$. 
Hipotesis 3:

Tabel 10. Koefisien Uji Regresi linear $X_{3}$ terhadap $Y$

\begin{tabular}{lccc}
\hline Model & \multicolumn{2}{l}{$\begin{array}{l}\text { Unstandardized } \\
\text { Coefficients }\end{array}$} & $\mathrm{P}$ \\
\cline { 2 - 3 } & $\mathrm{B}$ & $\begin{array}{l}\text { Std. } \\
\text { Error }\end{array}$ & \\
\hline (Constant) & -8.172 & 4.499 & 0,074 \\
Kemandirian & 1,175 & 0,077 & 0,000 \\
belajar & & & \\
\hline
\end{tabular}

Berdasarkan output analisis regresi ganda pada table 10 coefficients, dapat dilihat nilai $\beta_{3}=1,175$ dengan nilai $\mathrm{P}$ Value $=0,000$ pada taraf signifikan $a=0,05$ yang berarti $P$ Value $<0,05$. Hal tersebut berarti $\mathrm{H}_{0}$ ditolak dan $\mathrm{H}_{1}$ diterima, sehingga dapat disimpulkan bahwa terdapat pengaruh signifikan kemandirian belajar terhadap hasil belajar matematika siswa kelas XI SMKN 2 Makassar sebesar 78,8\%. Dari data tersebut dapat disusun persamaan regresinya sebagai berikut: $Y=-8,172+1,175 X_{3}$.

Hipotesis 3:

Tabel 11. Koefisien Uji Regresi linear $X_{1}, X_{2}, X_{3}$ terhadap $Y$

\begin{tabular}{lccc}
\hline Model & \multicolumn{2}{l}{$\begin{array}{l}\text { Unstandardized } \\
\text { Coefficients }\end{array}$} & \multirow{2}{*}{$\mathrm{P}$} \\
\cline { 2 - 3 } & $\mathrm{B}$ & \multicolumn{2}{l}{$\begin{array}{l}\text { Std. } \\
\text { Error }\end{array}$} \\
\hline (Constant) & -23.901 & 6.668 & 0,000 \\
Potensi akademik & 0,129 & 0,062 & 0,042 \\
Efikasi diri & 0,303 & 0,138 & 0,031 \\
Kemandirian belajar & 1.003 & 0,089 & 0,000 \\
\hline
\end{tabular}

Berdasarkan output analisis regresi ganda pada table 11 coefficients, dapat dilihat nilai $\beta_{1}=0,129$ dengan nilai $\mathrm{P}$ Value $=0,042$ pada taraf signifikan $a=0,05$ yang berarti $P$ Value $<0,05, \beta_{2}=0,138$ dengan nilai $P=0,031$ pada taraf signifikan $a=0,05$, yang berarti $\mathrm{P}$ Value $<0,05, \beta_{3}=1,003$. Hal tersebut berarti $\mathrm{H}_{0}$ ditolak dan $\mathrm{H}_{1}$ diterima.

Dari tabel ANOVA diperoleh nilai $F_{\text {hitung }}=96,489$. Untuk $F_{\text {tabel }}$ dengan taraf signifikan sebesar 5\%, diperoleh $\mathrm{F}_{\text {tabel }}=2,75$. Dan diperoleh nilai $\mathrm{P}$ value $0,000<0,05$, maka dapat disimpulkan bahwa $\mathrm{H}_{0}$ ditolak. Sehingga terdapat pengaruh signifikan antara potensi akademik, efikasi diri dan kemandirian belajar terhadap hasil belajar sebesar 81,7\%. Adapun persamaan regresi ganda yang diperoleh sebagai berikut:

$$
\mathrm{Y}=-23,901+0,129 X_{1}+0,303 X_{2}+1,003 X_{3}
$$




\subsection{Pembahasan}

\section{a. Potensi akademik}

Hasil analisis deskriptif menunjukkan bahwa potensi akademik berada pada kategori kurang dari 65 responden yang diteliti, diketahui bahwa tidak ada siswa siswa yang memperoleh nilai kategori sangat baik dan kategori baik, 20\% siswa yang memperoleh potensi akademik yang tergolong cukup. Dan $80 \%$ siswa yang memperoleh potensi akademik yang tergolong kurang. Berdasarkan hasil analisis deskriptif yang telah dilakukan dapat disimpulkan bahwa potensi akademik berada pada kategori kurang, hal ini dilihat berdasarkan skor rata-rata potensi akademik berjumlah 60,00 .

\section{b. Efikasi Diri}

Hasil analisis deskriptif menunjukkan bahwa diketahui efikasi diri berada pada kategori tinggi dari 65 responden yang diteliti, terdapat 40\% siswa yang memiliki efikasi diri yang tergolong sangat tinggi, 35,38\% siswa yang memiliki efikasi diri yang tergolong tinggi, 24,62\% siswa yang memiliki efikasi diri yang tergolong sedang. Dan tidak ada siswa yang memperoleh nilai kategori rendah dan sangat rendah. Berdasarkan hasil analisis deskriptif yang telah dilakukan dapat disimpulkan bahwa efikasi diri berada pada kategori sangat tinggi, hal ini dilihat berdasarkan skor rata-rata efikasi diri berjumlah 59,85 .

\section{c. Kemandirian Belajar}

Hasil analisis deskriptif menunjukkan bahwa diketahui kemandirian belajar berada pada kategori tinggi dari 65 responden yang diteliti, terdapat 40\% siswa yang memiliki kemandirian belajar yang tergolong sangat tinggi, 33,85\% siswa yang memiliki kemandirian belajar yang tergolong tinggi, 16,92\% siswa yang memiliki kemandirian belajar yang tergolong sedang, 9,23\% siswa yang tergolong memiliki kemandirian belajar rendah dan tidak ada siswa yang memperoleh nilai kategori sangat rendah. Berdasarkan hasil analisis deskriptif yang telah dilakukan dapat disimpulkan bahwa kemandirian belajar berada pada kategori sangat tinggi, hal ini dilihat berdasarkan skor rata-rata efikasi diri berjumlah 57,85.

\section{d. Hasil Belajar}

Hasil analisis deskriptif menujukkan bahwa diketahui hasil belajar berada pada kategori kurang dari 65 responden yang diteliti, diketahui bahwa tidak ada siswa siswa yang memperoleh nilai kategori sangat baik dan kategori baik, 16,92\% siswa yang memperoleh hasil belajar yang 
tergolong cukup. Dan $83,08 \%$ siswa yang memperoleh hasil belajar yang tergolong kurang. Berdasarkan hasil analisis deskriptif yang telah dilakukan dapat disimpulkan bahwa hasil belajar berada pada kategori kurang, hal ini dilihat berdasarkan skor rata-rata potensi akademik berjumlah 59,77 .

\section{e. Pengaruh potensi akademik terhadap hasil belajar matematika siswa pada materi matriks kelas XI SMK Negeri 2 Makassar}

Berdasarkan hasil analisis terdapat pengaruh positif antara variabel potensi akademik terhadap hasil belajar matematika siswa kelas IX SMK Negeri 2. Hal tersebut berdasarkan pada tabel Model Summary dengan $\mathrm{R}^{2}$ ( $\mathrm{R}$ square) sebesar 0,176 yang berarti hubungan antara variabel potensi akademik dengan hasil belajar menunjukkan hubungan sebesar 17,6\%. Pada tabel coefficients, dapat dilihat nilai $\beta_{1}=0,443$ dengan nilai $\mathrm{P}=0,001$ pada taraf signifikan $\alpha=$ 0,05 yang berarti $\mathrm{P}<0,05$. Hal tersebut berarti $\mathrm{H}_{0}$ ditolak dan $\mathrm{H}_{1}$ diterima, maka dapat disimpulkan bahwa potensi akademik siswa kelas XI SMK Negeri 2 Makassar berpengaruh positif terhadap hasil belajar matematika siswa.

\section{f. Pengaruh efikasi diri terhadap hasil belajar matematika siswa pada materi matriks kelas XI SMK Negeri 2 Makassar}

Berdasarkan hasil analisis terdapat pengaruh positif antara variabel efikasi diri terhadap hasil belajar matematika siswa kelas IX SMK Negeri 2. Hal tersebut berdasarkan pada tabel Model Summary dengan $\mathrm{R}^{2}$ ( $\mathrm{R}$ square) sebesar 0,434 yang berarti hubungan antara variabel efikasi diri dengan hasil belajar menunjukkan hubungan sebesar 43,4\%. Pada tabel coefficients, dapat dilihat nilai $\beta_{2}=1,296$ dengan nilai $\mathrm{P}=0,000$ pada taraf signifikan $\alpha=0,05$ yang berarti $\mathrm{P}<0,05$. Hal tersebut berarti $\mathrm{H}_{0}$ ditolak dan $\mathrm{H}_{1}$ diterima, maka dapat disimpulkan bahwa efikasi diri siswa kelas XI SMK Negeri 2 Makassar berpengaruh positif terhadap hasil belajar matematika siswa.

\section{g. Pengaruh kemandirian belajar terhadap hasil belajar matematika siswa pada materi matriks kelas XI SMK Negeri 2 Makassar}

Berdasarkan hasil analisis terdapat pengaruh positif antara variabel kemandirian belajar terhadap hasil belajar matematika siswa kelas IX SMK Negeri 2. Hal tersebut berdasarkan pada tabel Model Summary dengan $\mathrm{R}^{2}$ ( $\mathrm{R}$ square) sebesar 0,788 yang berarti hubungan antara variabel kemandirian belajar dengan hasil belajar menunjukkan hubungan sebesar 78,8\%. Pada tabel coefficients, dapat dilihat nilai $\beta_{3}=1,175$ dengan nilai $\mathrm{P}=0,000$ pada taraf signifikan $\alpha=$ 0,05 yang berarti $\mathrm{P}<0,05$. Hal tersebut berarti $\mathrm{H}_{0}$ ditolak dan $\mathrm{H}_{1}$ diterima, maka dapat 
disimpulkan bahwa kemandirian belajar siswa kelas XI SMK Negeri 2 Makassar berpengaruh positif terhadap hasil belajar matematika siswa.

\section{h. Pengaruh potensi akademik, efikasi diri dan kemandirian belajar terhadap hasil} belajar matematika pada materi matriks siswa kelas XI SMK Negeri 2 Makassar.

Berdasarkan hasil analisis terdapat pengaruh positif antara variabel potensi akademik,efikasi diri, dan kemandirian belajar terhadap hasil belajar matematika siswa kelas IX SMK Negeri 2. Hal tersebut berdasarkan pada tabel Model Summary dengan $\mathrm{R}^{2}$ (R square) sebesar 0,817 yang berarti hubungan antara variabel potensi akademik, efikasi diri dan kemandirian belajar dengan hasil belajar menunjukkan hubungan sebesar 81,7\%. Kemudian pada tabel coefficients diatas dapat dilihat nilai $\beta_{1}=0.129$ dengan nilai $\mathrm{P}=0,042$ pada taraf signifikan $a=0,05$ yang berarti $P<0,05, \beta_{2}=0,303$ dengan nilai $P=0,031$ pada taraf signifikan $a=0,05$, yang berarti $\mathrm{P}<0,05, \beta_{3}=1,003$ dengan nilai $P=0,000$ pada taraf signifikan $a=0,05$, yang berarti $\mathrm{P}<0,05$. Hal tersebut berarti $\mathrm{H}_{0}$ ditolak dan $\mathrm{H}_{1}$ diterima, maka dapat disimpulkan bahwa potensi akademik, efikasi diri dan kemandirian belajar siswa kelas XI SMK Negeri 2 Makassar berpengaruh positif terhadap hasil belajar matematika siswa.

\section{Kesimpulan}

Berdasarkan hasil analisis statistik deskriptif dan statistik inferensial, maka dapat disimpulkan sebagai berikut:

a. Terdapat pengaruh positif potensi akademik terhadap hasil belajar matematika siswa kelas XI SMK Negeri 2 Makassar dengan koefisien korelasi $\left(\mathrm{r}_{1}\right)$ sebesar 0,419 dan koefisien determinasi R square sebesar 0,176. Hal ini menunjukkan bahwa pengaruh potensi akademik terhadap hasil belajar matematika siswa sebesar 17,6\%.

b. Terdapat pengaruh positif efikasi diri terhadap hasil belajar matematika siswa kelas XI SMK Negeri 2 Makassar dengan koefisien korelasi $\left(\mathrm{r}_{1}\right)$ sebesar 0,659 dan koefisien determinasi R square sebesar 0,434. Hal ini menunjukkan bahwa pengaruh efikasi diri terhadap hasil belajar matematika siswa sebesar 43,4\%.

c. Terdapat pengaruh positif kemandirian belajar terhadap hasil belajar matematika siswa kelas XI SMK Negeri 2 Makassar dengan koefisien korelasi $\left(\mathrm{r}_{1}\right)$ sebesar 0,888 dan koefisien determinasi R square sebesar 0,788. Hal ini menunjukkan bahwa pengaruh kemandirian belajar terhadap hasil belajar matematika siswa sebesar 78,8\%.

d. Terdapat pengaruh positf potensi akademik, efikasi diri, dan kemandirian belajar secara bersama-sama terhadap hasil belajar matematika pada siswa kelas XI SMK Negeri 2 
Makassar dengan koefisien korelasi $\left(\mathrm{r}_{1,2,3}\right)$ sebesar 0,909 dan koefisien determinasi $\mathrm{R}$ square sebesar 0,817 . Hal ini menunjukkan bahwa pengaruh potensi akademik, efikasi diri, dan kemandirian belajar secara bersama-sama terhadap hasil belajar matematika sebesar $81,7 \%$.

Selain potensi akademik, efikasi diri dan kemandirian belajar masih ada faktor lain yang mempengaruhi hasil belajar oleh karena itu, Bagi peneliti selanjutnya, diharapkan melakukan pengembangan model penelitian dengan menggunakan variabel-variabel lain untuk mengetahui pengaruh hasil belajar matematika siswa. Dalam kegiatan pembelajarn matematika hendaknya guru berusaha menciptakan suasan belajar yang dapat menumbuhkan kepercayaan diri siswa dan kemampuan komunikasi matematika agar dapat membantu peserta didik dalam memahami dan mengerjakan soal-soal matematika.Bagi siswa hendaknya dapat menanamkan bahwa belajar merupakan hal yang menyenangkan dan merupakan kebutuhan bukan sebagai beban. Hal tersebut dapat dilakukan dengan menjadikan kegiatan belajar lebih menyenangkan seperti dengan berdiskusi dan memecahkan masalah bersama teman berkaitan dengan pelajaran.

\section{DAFTAR PUSTAKA}

Arifiin, S. W., \& Rahman, A. (2015). Profil pemecahan masalah matematika siswa ditinjau dari gaya kognitif dan efikasi diri pada siswa kelas VIII unggulan SMPN 1 Watampone. Jurnal Daya Matematis Matematika. Vol. 3, No. 1, Hal 20. http://ojs.unm.ac.id/JDM/article/view/1313/pdf_2. di akses tanggal 14 juni 2019

Bungsu, T. K., Vilardi, M., Akbar, P., \& Bernard, M. (2015). Pengaruh Kemandirian Belajar Terhadap Hasil Belajar Matematika di SMKN1 Cihampelas. Jurnal On Education. Vol. 1, No. 2, Hal 382. http://jonedu.org/index.php/joe/article/view/78/65. di akses tanggal 14 juni $\underline{2019}$

Hadaning, G. B. (2013). Hubungan Efikasi Diri dslam Persfektif Gender dengan Hasil Belajar Matematika Siswa Kelas X SMA Al-Azhar Mengati Gresik.

Nurul, A. B. (2016). Pengaruh Potensi Akademik, Kemampuan Berpikir Divergen, dan Kemandirian Belajar Terhadap Prestasi Belajar Matematika Siswa Kelas IX SMP Negeri 2 Sengkang. Makassar: Universitas Negeri Makassar.

Siregar, N. R. (2017). Persepsi Siswa Pada Pelajaran Matematika . Unisula Semarang.

Sunardi. (2015). Pengaruh Potensi Akademik, Efikasi Diri dan Kemandirian Belajar Terhadap Prestasi Bealajar Matematika . Universitas Negeri Makassar.

Susilo, G., \& Nur'aini, T., A. (2018). Pengaruh Potensi Akademik Prestasi Belajar Matematika. Jurnal Kajian Pendidikan Matematika. Vol. 4, No. 1, Hal 27. https://journal.lppmunindra.ac.id/index.php/jkpm/article/view/2975/2287. di akses tanggal 19 November 2019 
Widganinggar, A. A. (2015). Pengaruh Efikasi Diri (lokus of control) Terhadap Prestasi Belajar Matematika. Jurnal Ilmiah Pendidikan MIPA. Vol. 4, No. 2. Hal 89. https://journal.lppmunindra.ac.id/index.php/Formatif/article/view/143. di akses tanggal 1 